\title{
Factors Affecting the Development and Severity of Goss's Bacterial Wilt and Leaf Blight of Corn, Caused by Clavibacter michiganensis subsp. nebraskensis
}

Craig B. Langemeier, Department of Plant Pathology, University of Nebraska-Lincoln; Alison E. Robertson, Department of Plant Pathology and Microbiology, Iowa State University; Dong Wang, Statistics and Mathematics Group, Dow AgroSciences, formerly Department of Statistics, University of Nebraska-Lincoln; Tamra A. Jackson-Ziems, Department of Plant Pathology, University of Nebraska-Lincoln; and Greg R. Kruger, Department of Agronomy and Horticulture, University of Nebraska-Lincoln

\begin{abstract}
Goss's bacterial wilt and leaf blight, which is caused by Clavibacter michiganensis subsp. nebraskensis, is a disease of corn (Zea mays) that has been increasingly reported across the Midwest since its reemergence in western Nebraska, northeastern Colorado, and southeastern Wyoming during the 2006 growing season. The objective of this study was to identify environmental and agronomic factors contributing to the incidence of the disease across the Corn Belt through a multistate survey conducted during the 2011 growing season. Of the 2,400 surveys distributed throughout nine states, 486 were returned with corn leaf samples, of which $70 \%$ tested positive for C. michiganensis subsp. nebraskensis using an enzyme-linked immunosorbent assay. The agronomic data associated with each field were analyzed using classification and regression tree and random forest analyses to identify the factors that contributed

most to Goss's bacterial wilt and leaf blight development. A $\chi^{2}$ test of independence was also done to determine relationships between certain variables and disease incidence. The two best predictors of Goss's bacterial wilt and leaf blight were hybrid resistance to Goss's bacterial wilt and leaf blight, as indicated by the seed companies' score and a planting population density $>67,500$ plants $\mathrm{ha}^{-1}$. Other important predictors included longitude, planting date, crop rotation, percent residue, yield history, tillage, and growth stage. Relationships between glyphosate applications, foliar fungicide applications, and corn rootworm beetle with samples testing positive for $C$. michiganensis subsp. nebraskensis were also detected. These data contribute to our understanding of factors that increase the risk of Goss's bacterial wilt and leaf blight, and should enable more effective management practices to be adopted or developed.
\end{abstract}

Corn (Zea mays L.) is the most widely planted crop in the United States, with 35.8 million ha planted in 2015 as reported by the United States Department of Agriculture-National Agricultural Statistics Service (USDA-NASS). In 2013, USDA-NASS reported that 48.7 billion $\mathrm{kg}$ of corn were exported, making it vital to the country's economy. Since 2010, the presence of Goss's bacterial wilt and leaf blight has economically affected production in the top five corn-producing states of Illinois, Indiana, Iowa, Minnesota, and Nebraska (C. Bradley, personal communication; K. Wise, personal communication; A. Robertson, personal communication; D. Malvick, personal communication; T. Jackson-Ziems, personal communication). Corn hybrids susceptible to Goss's bacterial wilt and leaf blight have sustained yield losses of up to 50\% (Claflin 1999).

Clavibacter michiganensis subsp. nebraskensis (Vidaver and Mandel 1974) is a gram-positive bacterium that survives and overwinters in plant residues. The bacterium can infect corn throughout the growing season and cause Goss's bacterial wilt and leaf blight. This disease was first reported in three corn fields in Dawson County, Nebraska in 1969 (Wysong et al. 1973). Over the next 10 years, the disease was observed in additional counties and, by 1979, it was reported in 53 of the 93 counties within the state (Jackson et al. 2007). Goss's bacterial wilt and leaf blight was confirmed in the surrounding states of Iowa in 1971, Kansas in 1972 (Wysong et al. 1973), Colorado and South Dakota in 1974 (Vidaver and Mandel 1974), and Wyoming in 1979 (Jackson et al. 2007). From the mid- to late 1980 s through the early 2000s, the incidence of Goss's bacterial wilt and leaf blight was low, and the disease was only observed sporadically in cases where the corn plants were physically injured or

Corresponding author: T. A. Jackson-Ziems; E-mail: tjackson3@unl.edu

*The $\boldsymbol{e}$-Xtra logo stands for "electronic extra" and indicates that one supplementary figure is published online.

Accepted for publication 1 June 2016

C 2017 The American Phytopathological Society in very susceptible genetics, such as some popcorn fields (Jackson et al. 2007).

By 2006, Goss's bacterial wilt and leaf blight had reemerged in the regions of western Nebraska, southeastern Wyoming, and northeastern Colorado (Jackson et al. 2007). In September 2008, the disease was confirmed in 15 counties in Nebraska and 8 counties in Iowa (A. Robertson, unpublished data). The following year, prevalence of the disease increased in Nebraska, where samples submitted from 24 counties to the University of Nebraska-Lincoln Plant and Pest Diagnostic Clinic tested positive (A. Timmerman, personal communication). Reemergence of Goss's bacterial wilt and leaf blight was reported in Illinois (Bradley 2010), Missouri (Sweets and Hosack 2014), and South Dakota (Strunk 2012). First reports of the disease were also confirmed in Indiana in 2008 (Ruhl et al. 2009), Texas (Korus et al. 2011) and Minnesota in 2009 (Malvick et al. 2010), and Louisiana (Singh et al. 2015) and North Dakota in 2013 (Friskop et al. 2014).

As the name implies, Goss's bacterial wilt and blight has two phases: the systemic wilt phase and the leaf blight phase (Claflin 1999). The systemic wilt phase usually develops in association with an early-season wounding event and can kill young plants, leading to stand reduction. The wilt is caused by an accumulation of bacterial cells in the vascular bundles, which prevents water transportation, thus causing plant wilt and death. The wilt phase can also occur when plants are older but disease is usually less severe (Suparyono and Pataky 1989).

The leaf blight phase is more common and usually affects the plant canopy. Yield loss from the leaf blight phase is usually less than yield loss associated with the systemic wilt phase. Foliar symptoms include large, gray lesions with small, dark-green to black, water-soaked, irregular areas that develop at the margins of these expanding lesions and are commonly referred to as freckles. A sign of the leaf blight phase is a bacterial exudate that dries to leave a glistening appearance on leaf surfaces.

Factors that have likely favored the resurgence of Goss's bacterial wilt and leaf blight development include susceptible hybrids, continuous corn production with infested surface residue, and severe weather (Jackson et al. 2007). However, there may be other agronomic or environmental factors that contribute to disease development. 
The objectives of this research were to identify environmental and agronomic factors that may have contributed to the increased prevalence of Goss's bacterial wilt and leaf blight across the Corn Belt. To do this, we surveyed farmers across the Corn Belt and analyzed disease, agronomic, and environmental data collected using both classification and regression tree (CART) analysis (Breiman et al. 1984) and random forest analysis (Breiman 2001) to identify factors associated with the presence of Goss's bacterial wilt and leaf blight, and provide a clear graphical presentation of our results in the form of a classification tree. These data could be used to focus future research efforts and develop improved management recommendations. The research described here is part of an M.S. thesis, and portions of these results have been previously presented (Langemeier et al. 2012).

\section{Materials and Methods}

Generation of survey questions. A survey instrument (Supplementary Fig. S1) was developed to gather information on the development and severity of Goss's bacterial wilt and leaf blight as well as agronomic and environmental factors that might affect the spread and development of the disease in fields throughout the Corn Belt. Questions were based on previously reported information about the pathogen (Schuster 1975) and other common agronomic practices that have become prevalent in the region that might affect the spread and development of Goss's bacterial wilt and leaf blight. The survey instrument included 16 multiplechoice questions and 24 open-ended questions that allowed the various production systems being used and environmental factors that occurred in regions of the Corn Belt where Goss's bacterial wilt and leaf blight was suspected during the 2011 growing season to be understood.

Survey distribution. The survey instrument and a cover letter explaining the purpose and goals of the project, along with a 3.785-liter sealable plastic bag with directions for sample submission, were distributed in a $26.25-$ by $-35-\mathrm{cm}$ padded, self-addressed, postage-paid envelope to representatives in private industry, county extension educators, and crop consultants representing nine states: Nebraska, Iowa, South Dakota, Illinois, Indiana, Colorado, Kansas, Minnesota, and Missouri. Survey participants were asked to distribute the survey materials to assist producers and land managers reporting information in the survey. Completed surveys and samples were returned to the Plant and Pest Diagnostic Clinic at the University of Nebraska-Lincoln.

For the study, 2,400 survey packets were distributed upon request from late June through much of the 2011 summer. Samples were accepted from dent corn, sweet corn, and popcorn producers but were limited to a maximum of five surveys with leaf samples per producer. As an inducement, C. michiganensis subsp. nebraskensis testing was conducted at no cost on samples submitted with a completed survey and, thus, a free confirmation of the presence of C. michiganensis subsp. nebraskensis was provided. Individuals helping with the survey were asked to also complete and return survey forms from fields with no apparent Goss's bacterial wilt and leaf blight disease.

Testing for $C$. michiganensis subsp. nebraskensis. Leaf samples were refrigerated upon receipt and stored until processing. For each sample received, the presence or absence of Goss's wilt and leaf blight was determined as follows. Samples were visually examined for typical Goss's bacterial wilt and leaf blight symptoms and symptomatic leaves were cut and examined microscopically for bacterial streaming. In addition, an enzyme-linked immunosorbent assay (ELISA) ImmunoStrip test kit (product number ISK 44001/0025; Agdia Inc., Elkhart, IN) was used to test for the presence of $C$. michiganensis subsp. nebraskensis. Although this test kit was designed for C. michiganensis subsp. michiganensis, it is known to cross react with $C$. michiganensis subsp. nebraskensis (Korus et al. 2010). When corn leaf samples were tested for $C$. michiganensis subsp. nebraskensis, a clean pair of nitrile gloves and a sterile razor blade were used on every sample to reduce the chance of cross-contamination. The manufacturer's recommended procedures were followed. Samples that did not show typical symptoms but tested positive were checked for bacterial streaming as a precaution against false-positive results. Samples with typical symptoms but that tested negative were also checked for bacterial streaming. Putative $C$. michiganensis subsp. nebraskensis isolates were recovered from all positive samples on Corynebacterium nebraskense selective medium (Gross and Vidaver 1979), were single colony purified and stored on silica gel at $-20^{\circ} \mathrm{C}$. To confirm the identify of each isolate as Clavibacter michiganensis subsp. nebraskensis, Koch's postulates were completed. The disease was considered to be present in samples that had typical Goss's leaf blight symptoms, tested positive for bacterial streaming, tested positive using the Immunostrip, and from which an isolate of $C$. michiganensis subsp. nebraskensis was recovered.

Statistical analysis. All statistical analyses were done using $\mathrm{R}$ package (www.r-project.org).

A $\chi^{2}$ test of independence (Dowdy et al. 2004) was conducted on each of 26 agronomic and environmental variables for which data were collected, and the presence or absence of Goss's bacterial wilt and leaf blight in the leaf sample was used to test for independence between agronomic or environmental variables and Goss's bacterial wilt and leaf blight occurrence.

The CART analysis was conducted using the recursive partitioning and regression trees (rpart) function to create a classification tree of decision points and, thereby, identify agronomic and environmental factors that predict the development of Goss's bacterial wilt and leaf blight (Therneau and Atkinson 1997). This analysis uses a binary partitioning algorithm to divide the data in each node into increasingly homogenous subsets that are associated with disease development.

Random forest analysis was used to test the contribution of each predictor of Goss's bacterial wilt and leaf blight development in a classification tree generated using CART analysis. Random forest analysis generated decision trees from a random sample of the original data using the Gini index. The Gini coefficient was used as a measure of how each variable contributed to the homogeneity of the nodes from 0 (homogeneous) to 1 (heterogeneous). Thus, a lower mean Gini index implied greater importance (Breiman and Cutler 2007). A variable importance plot was constructed using the output of the Random Forest analysis.

Variables were only included in the analysis if they had at least 40 survey responses. We have also set 40 as the minimum node size for performing split analyses. Setting the minimum node size helps to reduce "noise" caused by a large number of very small nodes and to remove variables of less importance from the data set. Furthermore, we constructed the tree with the top 14 variables deemed to be the most important by Random Forest analysis and, in this case, used a minimum node size of 50. These top 14 variables were selected because they grouped together and apart from the other variables according to the Gini values generated by the Random Forest analysis output.

Only variables for which more than $50 \%$ of the returned surveys included data were included in the CART and Random Forest analyses. Furthermore, for open-ended questions, responses were arbitrarily grouped for analysis. This included data for latitude and longitude, plant population densities, and planting dates. Goss's bacterial wilt and leaf blight severity ratings for corn hybrids were also converted to a common scale. Corn seed companies report hybrid ratings in their seed catalogs but scales vary between companies. To facilitate our research in determining the association of hybrid rating with presence of Goss's bacterial wilt and leaf blight, we used a 1-to9 disease rating scale, with 1 being susceptible and 9 being resistant. This scale was used because the majority of hybrids grown in the fields that were surveyed were scored on this scale. For hybrids scored by companies on a 1-to-9 scale where 1 is resistant and 9 is susceptible, we inverted the ratings. If ratings were based on a 1-to-5 scale, the scale was doubled; therefore, 1, 2, 3, 4, and 5 became $2,4,6,8$, and 10 . The 1-to-10 scale was then transformed into a scale of 1 to 9 by rounding, where $0.9=1,1.8=2,2.7=3$, 
$3.6=4,4.5=5,5.4=5,6.3=6,7.2=7,8.1=8$, and $9.0=9($ Quinn and Keough 2002).

\section{Results}

Leaf samples accompanied by at least partially completed surveys were returned from 486 locations from eight of the nine states (none were received from Illinois) from late June through late October 2011 (Table 1). The majority of samples were received from Iowa and Nebraska (45.1 and $43.4 \%$, respectively). The remaining samples and surveys were returned from South Dakota (3.9\%), Indiana (3.1\%), Colorado (2.7\%), Kansas (0.8\%), Minnesota (0.6\%), and Missouri $(0.4 \%)$. Dent corn comprised $97 \%$ of samples returned, and the

Table 1. Number of corn leaf samples received and number of leaf samples testing positive for Clavibacter michiganensis subsp. nebraskensis in a 2011 survey of Goss's bacterial wilt and leaf blight occurrence in eight Midwestern states ${ }^{\mathrm{a}}$

\begin{tabular}{lccccccccc}
\hline Number of leaf samples & NE & IA & CO & IN & KS & MN & MO & SD & $\boldsymbol{N}$ \\
\hline Received & 211 & 219 & 13 & 15 & 4 & 3 & 2 & 19 & 486 \\
Testing positive $^{b}$ & 142 & 161 & 13 & 14 & 1 & 2 & 0 & 7 & 340 \\
\hline
\end{tabular}

a $\mathrm{NE}=$ Nebraska, IA = Iowa, $\mathrm{CO}=$ Colorado, IN = Indiana, KS = Kansas, $\mathrm{MN}=$ Minnesota, $\mathrm{MO}=$ Missouri, $\mathrm{SD}=$ South Dakota, and $N=$ total.

b Tested for using an ImmunoStrip (enzyme-linked immunosorbent assay) test kit (Agdia Inc., Elkhart, IN) for C. michiganensis subsp. michiganensis.

Table 2. Effects of the presence of common foliar diseases and insect pests of corn, alternative hosts for Clavibacter michiganensis subsp. nebraskensis, and use of pesticides and fertilizers with the presence of Goss's bacterial wilt and blight in a survey of fields conducted in eight Midwestern states in 2011

\begin{tabular}{|c|c|c|c|c|}
\hline \multirow[b]{2}{*}{ Factor ${ }^{b}$} & \multirow[b]{2}{*}{ Present $^{c}$} & \multicolumn{2}{|c|}{ Test for presence ${ }^{a}$} & \multirow[b]{2}{*}{$\begin{array}{c}P \\
\text { value }^{\mathrm{d}}\end{array}$} \\
\hline & & $\begin{array}{c}\text { Positive } \\
(\%)\end{array}$ & $\begin{array}{c}\text { Negative } \\
(\%)\end{array}$ & \\
\hline \multicolumn{5}{|l|}{ Other diseases $(327)^{\mathrm{e}}$} \\
\hline \multirow{2}{*}{ Gray leaf spot } & Yes & 61 & 19 & 0.3392 \\
\hline & No & 14 & 6 & \\
\hline \multirow[t]{2}{*}{ Northern corn leaf blight } & Yes & 17 & 6 & 0.9315 \\
\hline & No & 57 & 20 & \\
\hline \multirow[t]{2}{*}{ Common rust } & Yes & 10 & 3 & 0.8762 \\
\hline & No & 65 & 22 & \\
\hline \multirow[t]{2}{*}{ Eye spot } & Yes & 14 & 4 & 0.5702 \\
\hline & No & 61 & 21 & \\
\hline \multicolumn{5}{|l|}{ Insect feeding (200) } \\
\hline \multirow[t]{2}{*}{ Root feeding } & Yes & 48 & 5 & 0.0005 \\
\hline & No & 33 & 14 & \\
\hline \multirow[t]{2}{*}{ Ear feeding } & Yes & 43 & 9 & 0.6494 \\
\hline & No & 38 & 10 & \\
\hline \multirow[t]{2}{*}{ Leaf feeding } & Yes & 18 & 9 & 0.0005 \\
\hline & No & 63 & 10 & \\
\hline \multicolumn{5}{|l|}{ Corn insect pests $(200)^{\mathrm{f}}$} \\
\hline \multirow[t]{2}{*}{ Corn rootworm } & Yes & 59 & 10 & 0.0258 \\
\hline & No & 22 & 9 & \\
\hline \multirow[t]{2}{*}{ Corn borer } & Yes & 15 & 4 & 0.9673 \\
\hline & No & 66 & 15 & \\
\hline \multirow[t]{2}{*}{ Aphid } & Yes & 11 & 4 & 0.4226 \\
\hline & No & 70 & 15 & \\
\hline
\end{tabular}

a Test for the presence of Clavibacter michiganensis subsp. nebraskensis.

b Number in parentheses indicates total number of survey responses.

c Factors that are or are not present or, in the case of insect feeding, evident.

d Symptomatic leaves observed microscopically for bacterial streaming and tested with ImmunoStrip (enzyme-linked immunosorbent assay) test kit (Agdia Inc., Elkhart, IN) for presence of $C$. michiganensis subsp. nebraskensis according to $\chi^{2}$ test of independence.

e Gray leaf spot (Cersospora zeae-maydis), northern leaf blight (Setosphaeria turcica), common rust (Puccinia sorghi), and eyespot (Aureobasidium zeae).

f Corn rootworm (Diabrotica spp.), corn borer (Ostrinia nubilalis Hubner), and aphids (order Hemiptera; family Aphididae). remaining 3\% were popcorn samples. Among the surveys received, Goss's wilt and leaf blight was determined to be present in $70 \%$ of the samples that were received. The disease was not present in samples received from Missouri.

Relationships between agronomic factors and the detection of $\boldsymbol{C}$. michiganensis subsp. nebraskensis. In the survey, questions regarding the presence of Goss's wilt and other diseases, insect pests, and weed management were included. The four most commonly reported diseases in the survey were gray leaf spot (caused by Cercospora zeae-maydis Tehon \& E. Y. Daniels), common rust (caused by Puccinia sorghi Schwein.), eyespot (caused by Aureobasidium zeae (Narita \& Y. Hirats.) Dingley), and northern corn leaf blight (caused by Setosphaeria turcica (Luttr.) K. J. Leonard \& Suggs). No relationship were detected between the occurrence of these diseases in the field and the detection of Clavibacter michiganensis subsp. nebraskensis $(P>0.05)$ (Table 2).

A relationship was observed between reported insect root feeding $(P<0.01)$ and leaf feeding $(P<0.01)$ and the presence of Goss's bacterial wilt and leaf blight (Table 2). Although corn rootworm (Diabrotica spp.), corn borer (Ostrinia nubilalis Hubner), aphids (order Hemiptera; family Aphididae), corn earworm (Helicoverpa zea Boddie), and grasshoppers (order Orthoptera; family Acrididae) were reported in the survey, Goss's bacterial wilt and leaf blight was only present when corn rootworm was present in the field $(P<0.05$; Table 2$)$.

Weed species that were reported in the corn fields sampled as part of the Goss's bacterial wilt and leaf blight survey were foxtail species

Table 2. (continued from preceding column)

\begin{tabular}{|c|c|c|c|c|}
\hline \multirow[b]{2}{*}{ Factor $^{\mathbf{b}}$} & \multirow[b]{2}{*}{ Present $^{c}$} & \multicolumn{2}{|c|}{ Test for presence ${ }^{a}$} & \multirow[b]{2}{*}{$\begin{array}{c}P \\
\text { value }^{\mathrm{d}}\end{array}$} \\
\hline & & $\begin{array}{l}\text { Positive } \\
(\%)\end{array}$ & $\begin{array}{l}\text { Negative } \\
(\%)\end{array}$ & \\
\hline \multicolumn{5}{|c|}{ Alternative hosts (170) } \\
\hline Current season & $\begin{array}{l}\text { Yes } \\
\text { No }\end{array}$ & $\begin{array}{l}21 \\
54\end{array}$ & $\begin{array}{r}6 \\
19\end{array}$ & 0.8126 \\
\hline Preceding season & $\begin{array}{l}\text { Yes } \\
\text { No }\end{array}$ & $\begin{array}{l}22 \\
54\end{array}$ & $\begin{array}{r}6 \\
18\end{array}$ & 0.8999 \\
\hline \multicolumn{5}{|c|}{$\begin{array}{l}\text { Fungicide, insecticide } \\
\text { (486) }\end{array}$} \\
\hline Foliar fungicide & $\begin{array}{l}\text { Yes } \\
\text { No }\end{array}$ & $\begin{array}{l}26 \\
45\end{array}$ & $\begin{array}{r}6 \\
23\end{array}$ & 0.0010 \\
\hline Foliar insecticide & $\begin{array}{l}\text { Yes } \\
\text { No }\end{array}$ & $\begin{array}{l}15 \\
56\end{array}$ & $\begin{array}{r}6 \\
23\end{array}$ & 0.6433 \\
\hline \multicolumn{5}{|l|}{ Herbicides used (397) } \\
\hline Glyphosate & $\begin{array}{l}\text { Yes } \\
\text { No }\end{array}$ & $\begin{array}{l}54 \\
19\end{array}$ & $\begin{array}{l}16 \\
11\end{array}$ & 0.0101 \\
\hline Atrazine & $\begin{array}{l}\text { Yes } \\
\text { No }\end{array}$ & $\begin{array}{l}41 \\
33\end{array}$ & $\begin{array}{l}14 \\
12\end{array}$ & 0.8037 \\
\hline Metolachlor & $\begin{array}{l}\text { Yes } \\
\text { No }\end{array}$ & $\begin{array}{l}26 \\
48\end{array}$ & $\begin{array}{r}9 \\
17\end{array}$ & 0.9334 \\
\hline Acetochlor & $\begin{array}{l}\text { Yes } \\
\text { No }\end{array}$ & $\begin{array}{l}26 \\
48\end{array}$ & $\begin{array}{r}9 \\
17\end{array}$ & 0.9834 \\
\hline \multicolumn{5}{|c|}{ Nitrogen applied (390) } \\
\hline Preplant & $\begin{array}{l}\text { Yes } \\
\text { No }\end{array}$ & $\begin{array}{l}55 \\
19\end{array}$ & $\begin{array}{r}21 \\
5\end{array}$ & 0.0862 \\
\hline At planting & $\begin{array}{l}\text { Yes } \\
\text { No }\end{array}$ & $\begin{array}{l}29 \\
45\end{array}$ & $\begin{array}{r}8 \\
18\end{array}$ & 0.1549 \\
\hline Side-dressing & $\begin{array}{l}\text { Yes } \\
\text { No }\end{array}$ & $\begin{array}{l}19 \\
55\end{array}$ & $\begin{array}{r}7 \\
19\end{array}$ & 0.9162 \\
\hline \multicolumn{5}{|c|}{ Phosphorous applied (292) } \\
\hline Preplant & $\begin{array}{l}\text { Yes } \\
\text { No }\end{array}$ & $\begin{array}{l}50 \\
25\end{array}$ & $\begin{array}{r}19 \\
6\end{array}$ & 0.2627 \\
\hline At planting & $\begin{array}{l}\text { Yes } \\
\text { No }\end{array}$ & $\begin{array}{l}31 \\
43\end{array}$ & $\begin{array}{l}10 \\
16\end{array}$ & 0.6216 \\
\hline \multicolumn{5}{|c|}{ Potassium applied (212) } \\
\hline Preplant & $\begin{array}{l}\text { Yes } \\
\text { No }\end{array}$ & $\begin{array}{l}59 \\
14\end{array}$ & $\begin{array}{r}22 \\
5\end{array}$ & 0.8964 \\
\hline At planting & $\begin{array}{l}\text { Yes } \\
\text { No }\end{array}$ & $\begin{array}{l}19 \\
54\end{array}$ & $\begin{array}{r}8 \\
19\end{array}$ & 0.6803 \\
\hline
\end{tabular}


(Setaria spp.), giant foxtail (Setaria faberi Herrm.), green foxtail (S. viridis (L.) Beauv.), woolly cupgrass (Eriochloa villosa (Thunb.) Kunth), and sandbur (Cenchrus longispinus (Hack.) Fern.). The survey also asked whether foxtail species, woolly cupgrass, and crabgrass (Digitaria spp.) were present during the previous season. Green foxtail has been reported as an alternative host of Clavibacter michiganensis subsp. nebraskensis (Schuster 1975; Wysong et al. 1981). No relationship was observed between the presence of these weed species in a field during the 2010 or 2011 growing season and the presence of Goss's bacterial wilt and leaf blight (data not shown).

A relationship between Goss's bacterial wilt and leaf blight and the use of a foliar fungicide $(P<0.01)$ or the herbicide glyphosate $(P=0.01)$ was detected (Table 2$)$. However, applications of insecticides and herbicides did not affect the presence of the disease. Similarly, no relationships were observed between the application or timings of nutrient application and the presence of $C$. michiganensis subsp. nebraskensis (Table 2).

Model development. Only questions from the survey for which more than 243 responses ( $\geq 50 \%$ of surveys) were recorded were used in the CART and Random Forest analyses. An inadequate number of responses ( $<50 \%$ of surveys) occurred for the questions that asked about alternative crops planted, amount of irrigation water applied, history of disease severity, estimates of insect damage, estimates of weed density from both the current and past growing seasons, insecticide and herbicides rates, rate and timing of foliar fungicide application, and the amount of any nutrients applied. Questions regarding the history of Goss's bacterial wilt and leaf blight disease severity in the field, Goss's bacterial wilt and leaf blight severity in 2011, and estimated yield loss due to Goss's bacterial wilt and leaf blight were also removed from the data set due to the subjective nature of the responses.

The classification tree that was generated using all 40 variables is shown in Figure 1. The most important factors for Goss's bacterial wilt and leaf blight development are at the top of the tree, and factors become less important toward the base.

Plant population was the best predictor of the presence of Goss's bacterial wilt and leaf blight, followed by the susceptibility of the corn hybrid to the Goss's bacterial wilt and leaf blight disease rating for the hybrid (provided by the seed company), longitude, and planting date. CART analysis showed that more Goss's bacterial wilt and leaf blight was confirmed on samples received from fields with high plant population densities. Of the samples submitted from fields with $>67,500$ seeds ha $^{-1}$ planted, the disease was present in $75 \%$ of samples (Fig. 1). For leaf samples received from fields in which hybrids with a Goss's bacterial wilt and leaf blight resistance rating of $<5.2$ were planted, the disease was present in $88 \%$ of the samples. When samples were submitted from fields planted with more resistant (>5.2) hybrids, Goss's bacterial wilt and leaf blight was determined to be present in $70 \%$ of the samples. Location longitude also played a role in predicting the frequency of positive samples. East of longitude 95.73W (Iowa, Minnesota, Missouri, and Indiana), 65\% of samples were positive for the presence of Goss's bacterial wilt and leaf blight whereas, west of 95.73W (Colorado, Kansas, Nebraska, and South Dakota), $94 \%$ were positive. Thus, the disease was more likely to be present on a resistant hybrid in the western half of the region sampled. Goss's bacterial wilt and leaf blight also was more likely to be present in fields east of $95.73 \mathrm{~W}$ that were planted after 23 April. Other variables that affected the presence of Goss's bacterial wilt and leaf blight in samples from fields in Iowa, Minnesota, Missouri,

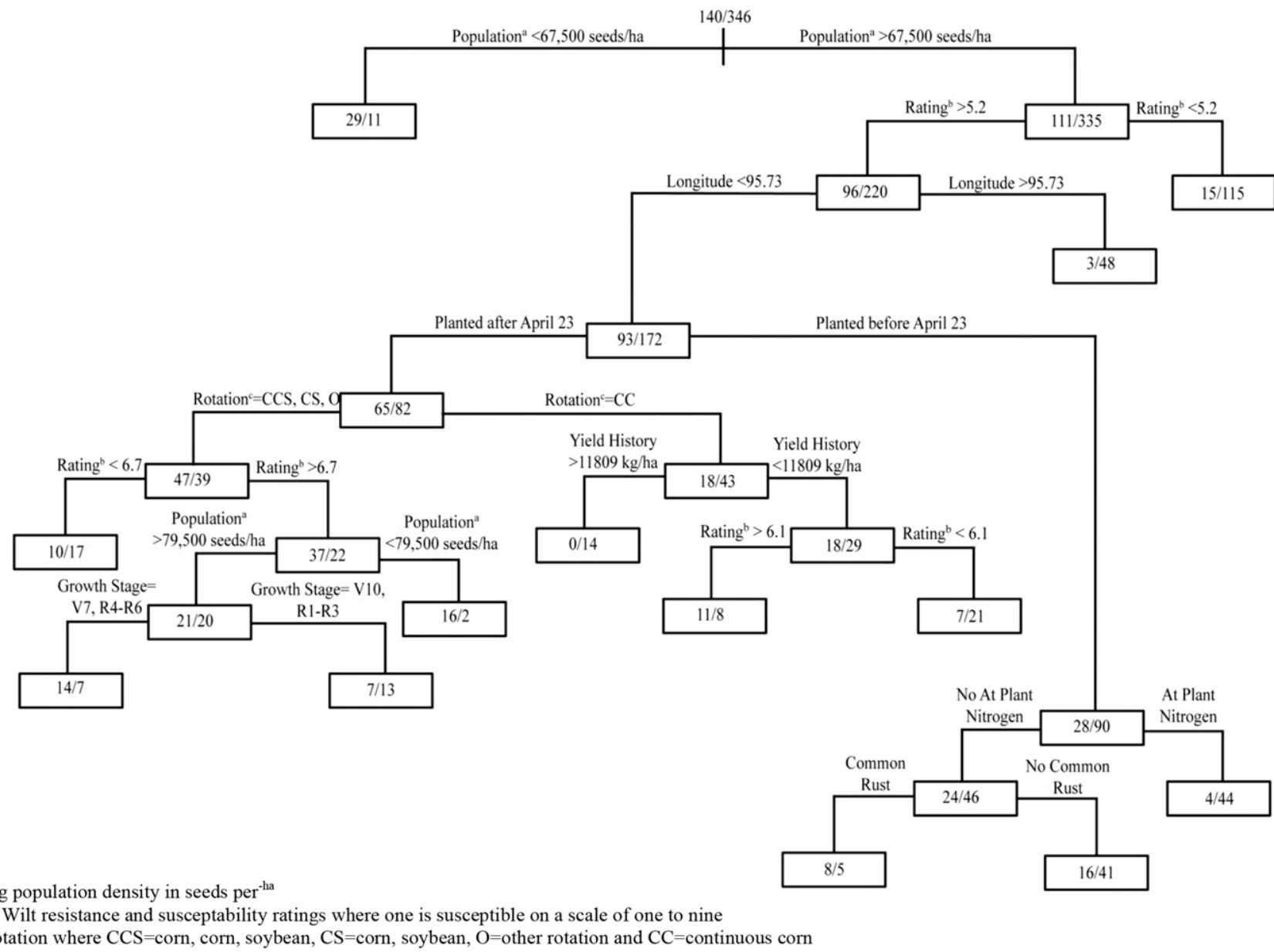

${ }^{a}$ Planting population density in seeds per-h

boss's Wilt resistance and susceptability ratings where one is susceptible on a scale of one to nine

${ }^{\mathrm{c}} \mathrm{Crop}$ rotation where $\mathrm{CCS}=$ corn, corn, soybean, $\mathrm{CS}=$ corn, soybean, $\mathrm{O}=$ other rotation and $\mathrm{CC}=$ continuous corn

Fig. 1. Classification and regression tree analysis of all 40 variables with the most important variables for the development of Goss's bacterial wilt and leaf blight at the top. The number of positive samples is presented on the right in each box and the number of negative samples is presented on the left. 
and Indiana included cropping history, growth stage of the crop at the time of the survey, yield history, nitrogen applied at planting, and the presence of common rust.

A variable importance plot was constructed from the Random Forest analysis (Fig. 2). Random Forest analysis differed from the CART analysis in that the assigned Goss's bacterial wilt and leaf blight rating for hybrids was the most important variable predicting whether Goss's bacterial wilt and leaf blight was present in a sample, followed by plant population density. Furthermore, planting date and longitude were less important at predicting the presence of disease in the Random Forest analysis than the CART analysis. Planting date was ranked fourth after crop rotation while longitude was ranked tenth after variables that included percent surface covered by residue and tillage, yield history, growth stage at the time of sampling, and preplant nitrogen applications.

According to the Random Forest analysis, the variables separated into two groups based on importance in predicting the likelihood that a sample would be positive for the presence of Goss's bacterial wilt and leaf blight (Fig. 2). The first group contained the 14 most important variables and these were used to reconstruct a second classification tree regarding the presence or absence of Goss's bacterial wilt and leaf blight. In this model, plant population followed by assigned Goss's bacterial wilt and leaf blight hybrid rating, longitude, and planting date were the four most important predictors of Goss's bacterial wilt and leaf blight presence (Fig. 3). Thereafter, the presence of the disease was more likely in fields east of $95.73 \mathrm{~W}$ that were irrigated or in continuous corn production.

\section{Discussion}

In this study, we used CART (Breiman et al. 1984) and Random Forest (Breiman 2001) analyses to identify factors that could predict the risk of Goss's bacterial wilt and leaf blight within corn fields across the Corn Belt. CART has been utilized to a limited extent in weed science and plant pathology (Copes and Scherm 2010; Davis et al. 2009; Gleason et al. 1994; Kim et al. 2002; Paul and Munkvold 2004; Williams et al. 2009) to identify risk factors and guide management strategies. For example, Paul and Munkvold (2004) reported surface residue, planting date, hybrid resistance, and longitude were the most important predictors of gray leaf spot, caused by Cercospora zeae-maydis. CART generates a regression or classification tree that can be easily understood by practitioners due to its graphical nature even if the data set is very complex (Williams et al. 2009). Other strengths of CART include its ability to handle missing data or handle data that are highly skewed, multimodal, categorical, or either ordinal or nonordinal in structure (Lewis 2000).

The primary downside to CART is that it is relatively unstable (Hastie et al. 2001); however, this can be overcome by using Random Forest analysis, which constructs a large number of trees on bootstrap samples and averages the output (Breiman 2001). Random Forest analysis also handles missing data, avoids overfitting (Breiman 2002), and is not overly sensitive to the choice of tuning parameters. A disadvantage of Random Forrest, however, is that it can lose the simple interpretability of a single tree because data are averaged over a large number of trees.

Goss's bacterial wilt and leaf blight was widespread and severe across the Corn Belt during the 2011 growing season, most likely because weather conditions were favorable for infection and disease development and highly susceptible hybrids were still commonly used in some areas. In 2012 and 2013, the disease was less prevalent due to drought conditions across the area and also because of increased use of less-susceptible hybrids and rotation to nonhost crops in the worst affected areas. In our survey, almost 500 corn fields were sampled throughout the Midwest during the 2011 growing season. Although data from the survey were collected subjectively, there was a good balance between fields from which leaf samples tested positive for Clavibacter michiganensis subsp. nebraskensis and fields from which samples tested negative (70 and 30\%, respectively). Based on these numbers, we felt confident that differences in production practices for the producers who did or did not have Goss's bacterial wilt and leaf blight enabled us to detect factors that influence disease development. We acknowledge that these data are based on 1 year; however, because the disease reached epidemic proportions in 2011, we propose that this increased the likelihood of detecting factors that are important predictors of Goss's bacterial wilt and leaf blight.

Goss's bacterial wilt and leaf blight development is favored by growing hybrids that are susceptible to the disease, continuous corn production and reduced tillage practices that allow inoculum to

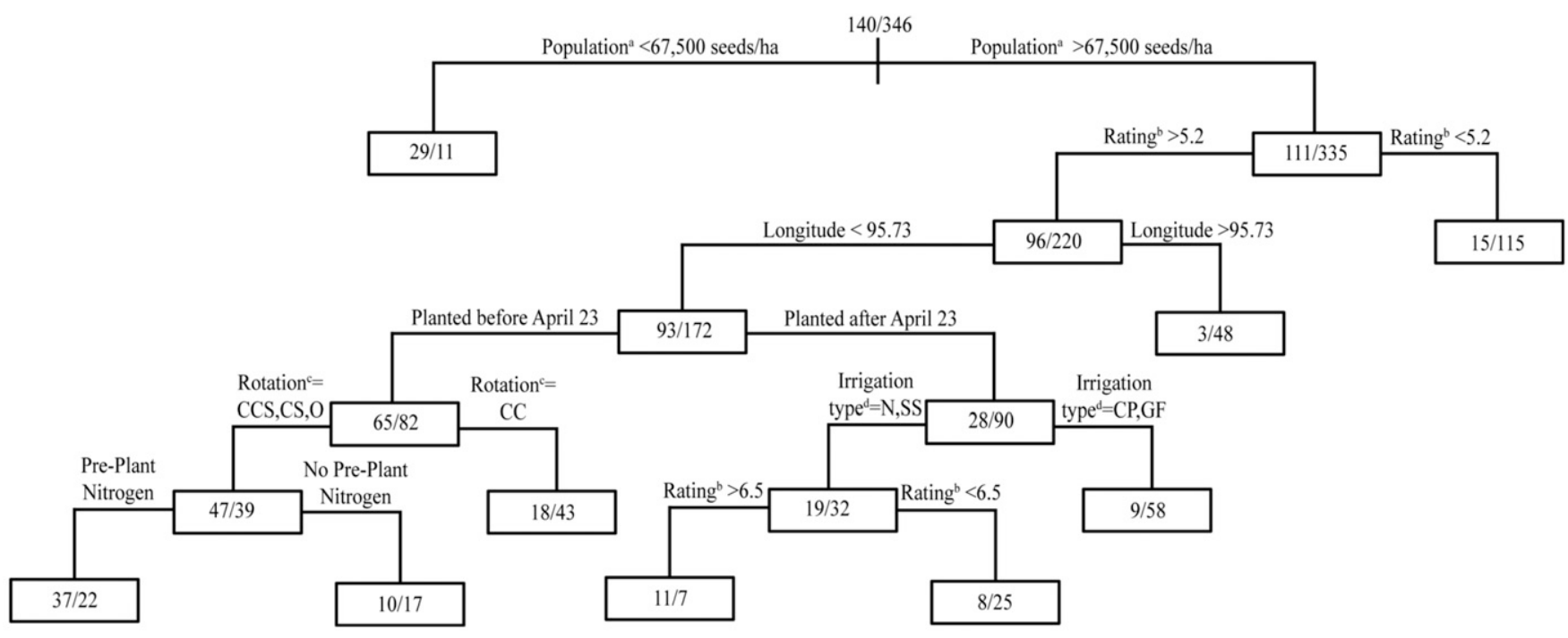

Planting population density in seeds per ${ }^{\text {-ha }}$

${ }^{b}$ Goss's Wilt resistance and susceptability ratings where one is susceptible on a scale of one to nine

${ }^{\mathrm{C}} \mathrm{Crop}$ rotation where $\mathrm{CCS}=$ corn, corn, soybean, $\mathrm{CS}=$ corn, soybean, $\mathrm{O}=$ other rotation and $\mathrm{CC}=$ continuous corn

Type of irrigation used where $\mathrm{N}=$ none, $\mathrm{SS}=$ sub-surface irrigation, $\mathrm{CP}=$ center pivot and $\mathrm{GF}=$ gravity/flood

Fig. 2. Classification and regression tree analysis of the top 14 factors as produced by the Random Forest output for the development of Goss's bacterial wilt and leaf blight at the top with the most important factors. The number of positive samples is presented on the right in each box and the number of negative samples is represented to the left. 
persist, and weather events that wound plants and enable infection (Jackson et al. 2007). As expected, the Goss's bacterial wilt and leaf blight hybrid resistance rating assigned by each company was the second or most important (CART and Random Forest analysis, respectively) predictive variable for a sample to be positive for the presence of Goss's bacterial wilt and leaf blight, indicating that there was a higher probability of the disease when planting a more susceptible hybrid. Jackson et al. (2007) reported that, prior to 2006, only $25 \%$ of seed companies in Nebraska publicized their hybrids' resistance ratings in seed catalogs to Goss's bacterial wilt and leaf blight. Based on data from the survey, $90 \%$ of seed companies from which samples originated had published Goss's bacterial wilt and leaf blight hybrid resistance ratings in 2011. Publishing rating scores for disease resistance is important for disease management because it allows producers to take scores into consideration when selecting hybrids for planting. Survey data support hybrid selection as the best management tool to protect a field from Goss's bacterial wilt and leaf blight.

Crop rotation and percent residue cover were among the top five variables with which the presence of Goss's bacterial wilt and leaf blight was associated. The pathogen survives well in surface residue (Schuster 1975; Smidt and Vidaver 1986) and, consequently, the disease is more likely to occur in no-till or reduced-till fields, where more crop residue is left on the soil surface (Schuster 1975). Crop rotation that incorporates nonhost plants is a key factor in reducing population densities of plant pathogens, weeds, and insect pests (Liebman and Dyck 1993; Peters et al. 2003; Wright 1984). Over the past few years, fluctuating grain prices have resulted in an increase in continuous corn cropping in the Midwest. This practice, together with reduced tillage, has likely facilitated survival of C. michiganensis subsp. nebraskensis and development of Goss's bacterial wilt and leaf blight throughout the region (Jackson et al. 2007).

Surprisingly, plant population density was an important predictor of the presence of Goss's bacterial wilt and leaf blight. In fact, if a sample was received from a field planted to a susceptible hybrid $(<5.2$ rating) at more than 67,500 seeds/ha, the disease was present in $88 \%$ of samples (Figs. 1 and 3). Optimal seeding rates across the region varied from 64,000 to 89,000 seeds/ha, with 74,100 to 81,500 seeds/ha being most common. We hypothesize that, in higher plant populations, plants are closer to each other, facilitating pathogen spread down and across rows. Eggenberger et al. (2016) recently demonstrated dissemination of $C$. michiganensis subsp. nebraskensis and subsequent disease development along and across rows from a point source of inoculum. In their trials, new lesions of Goss's leaf blight were often first observed on leaves that were physically touching symptomatic leaves. Changes in plant population likely also affect the microclimate within the canopy. Higher relative humidity within the canopy may favor survival of the bacterium. C. michiganensis subsp. nebraskensis, which has an epiphytic stage (Mallowa et al. 2016; Smidt and Vidaver 1986) and increased relative humidity were recently reported to promote survival of epiphytic populations of the bacterium in the greenhouse (Mallowa et al. 2016). Furthermore, the pathogen frequently oozes from diseased tissue onto the leaf surface in an exudate from which it could be easily dispersed. Because Goss's bacterial wilt and leaf blight was present more frequently in samples collected from center-pivot-irrigated fields (Fig. 2), survival of the pathogen may be favored by higher humidity, because the use of aboveground irrigation results in a more humid environment.

Plant growth stage was an important variable for determining the presence of Goss's bacterial wilt and leaf blight in survey samples according to the Random Forest analysis. We suspect that this may be related to when fields were sampled because only $10 \%$ of fields were sampled prior to the silking (R1) growth stage. Most leaf samples were received from fields that were sampled during early to mid grainfill, when symptoms of the disease were likely more noticeable or because producers and agronomists are usually scouting fields at this time. Suparyono and Pataky (1989) showed that plants inoculated at earlier stages were more susceptible to Goss's bacterial wilt and leaf blight development than those inoculated at later vegetative stages.

A number of interesting relationships were observed between various agronomic factors and the presence of Goss's bacterial wilt and leaf blight in a field. Applications of glyphosate or foliar fungicides were each correlated with samples that were positive for the disease (Table 2). This may be because 70 and $32 \%$ of the fields surveyed received an application of glyphosate and foliar fungicide, respectively. However, there also are several reasons why these practices could increase the risk of Goss's bacterial wilt and leaf blight. Glyphosate is the primary product used for weed control in the Corn Belt, and postemergent weed management is often required in reduced tillage fields. It is unknown whether the active ingredient in these applications drives the relationship we detected, because there are reports of crop diseases increasing when glyphosate is used to manage weeds (Johal and Huber 2009). No relationships were detected
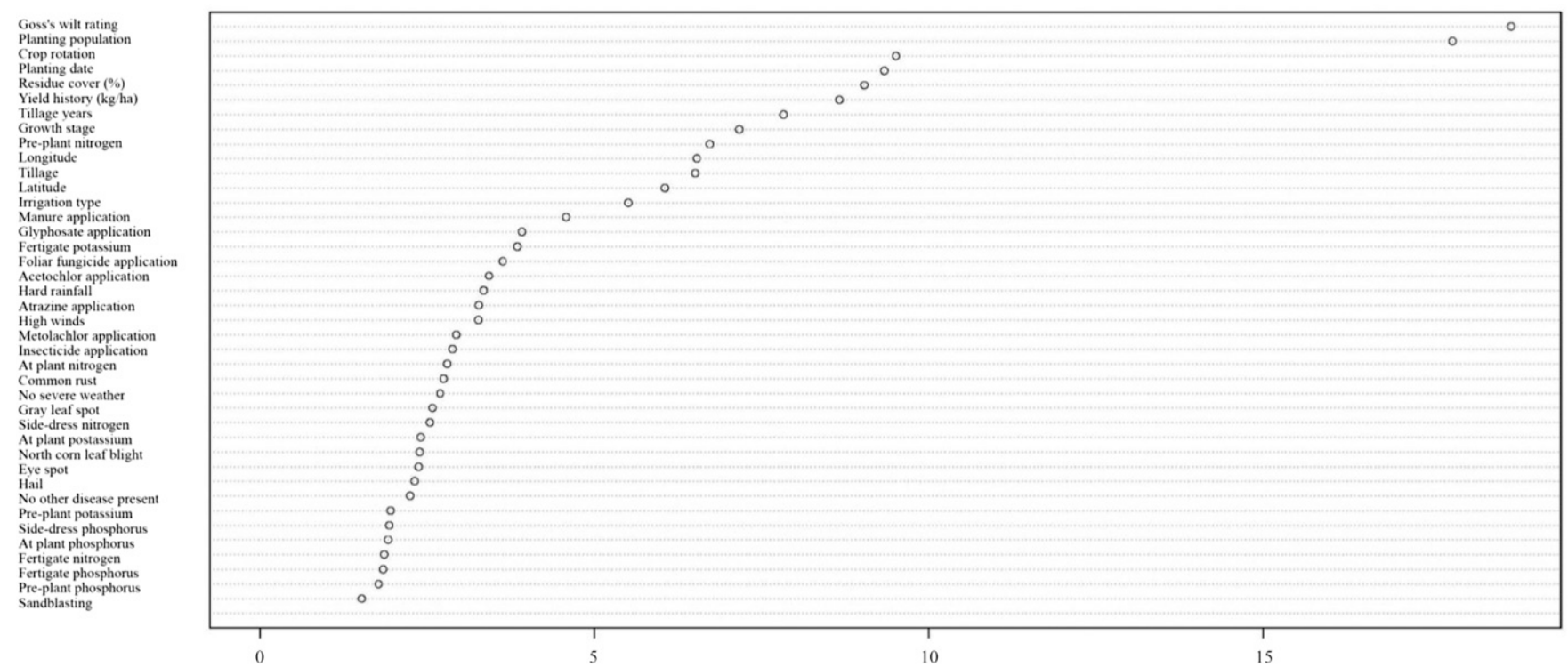

Gini Measure

Fig. 3. Random Forest analysis of 40 variables listed in order of importance for Goss's bacterial wilt and leaf blight development. Variables were ranked by Gini Measure, with higher scores indicating increased impact. 
between the presence of $C$. michiganensis subsp. nebraskensis and the other three commonly used herbicide active ingredients reported in the survey.

The use of foliar fungicides for increased plant health and harvestability has increased dramatically with higher corn prices and other trends (Wise and Mueller 2011). Adjuvants and carriers used with herbicides and fungicides may affect crop growth and development (Below et al. 2009) but there are limited reports on their effect on disease. Furthermore, application machinery driving through fields during ground applications may cause injury to plants that enable pathogen infection. Data from field (Schlund 2015) and greenhouse (Schlund et al. 2016) research with glyphosate, foliar fungicides, and adjuvant applications did not show an increase in Goss's bacterial wilt and leaf blight incidence or severity. Research has investigated potential interactions of glyphosate use and traits for glyphosate resistance and Lepidopteran insect resistance (Bt) on Goss's wilt and blight development in sweet corn. Williams et al. (2015) reported no difference in disease incidence in isogenic lines of sweet corn with and without glyphosate use or glyphosate and Bt traits.

There have been concerns in the Midwest that leaf feeding, particularly by the corn rootworm, could facilitate infection of corn by C. michiganensis subsp. nebraskensis. Corn rootworms feed on the roots as juveniles, and on the silks and leaves as adults (Chiang 1973). Because the disease often occurs after a wounding event such as hail, high winds, hard rainfall, or sandblasting (Claflin 1999), the wound from an insect feeding site may also allow the pathogen to enter the plant. A relationship was noted between root- and leaf-feeding insects, the presence of corn rootworm in the field being sampled, and the presence of Goss's bacterial wilt and leaf blight (Table 2). Thus, these data suggest the potential for the pathogen to enter through wounds in the root system, which was previously suggested by Schuster (1975).

Since this survey and its analysis were done, several more weed species have been reported as alternative hosts for $C$. michiganensis subsp. nebraskensis. Ikley et al. (2015) reported annual ryegrass (Lolium multiflorum L.), Johnsongrass (Sorghum halepense L.), and large crabgrass (Digitaria sanguinalis (L.) Scop.), while Langemeier et al. (2014) reported four Setaria spp.: Setaria viridis (green foxtail), S. faberi (giant foxtail), S. verticillata L. Beauv. (bristly foxtail), and $S$. pumila (Poir.) Roem. \& Schult. (yellow foxtail). This survey did not collect data on the presence or absence of these weed species and presence of Goss's bacterial wilt and leaf blight.

The goal of our survey was to identify agronomic and environmental factors that might play a role in Goss's bacterial wilt and leaf blight development and, therefore, guide future research on this economically important pathosystem. Our survey identified several factors that may play a role in disease development and have contributed to the reemergence of this disease. Many of these factors must be tested to understand their role in Goss's bacterial wilt and leaf blight disease development. Such data are required to enable improved management recommendations to be developed. For now, however, planting resistant hybrids, using a crop rotation that includes nonhost crops, and reducing the amount of inoculum by incorporating residue can mitigate the spread, development, and severity of Goss's bacterial wilt and leaf blight.

\section{Acknowledgments}

This work was supported by the USDA National Institute of Food and Agriculture, North Central Regional IPM Grants Program project 2011-34103-30714. We thank public and private industry collaborators for their assistance in conducting the survey and A. Timmerman and D. Pederson of the University of NebraskaLincoln Plant and Pest Diagnostic Clinic for technical assistance.

\section{Literature Cited}

Below, F. E., Duncan, K. A., Uribelarrea, M., and Ruyle, T. B. 2009. Occurrence and proposed cause of hollow husk in maize. Agron. J. 101:237-242.

Bradley, C. A. 2010. Uncommon diseases of corn observed. Pages 117-122 in: The Bulletin: Pest Management and Crop Development Information for Illinois. Online publication. University of Illinois Extension. http://bulletin.ipm.illinois. edu/print.php?id=1385

Breiman, L. 2001. Random forests. Mach. Learn. J. 45:5-32.
Breiman, L. 2002. Manual on Setting Up, Using, and Understanding Random Forests v4.0. Online publication. http://www.stat.berkeley.edu/ breiman/ Using_random_forests_v4.0.pdf

Breiman, L., and Cutler, A. 2007. Random Forest. Online publication. http://www. stat.berkeley.edu/ breiman/RandomForests/cc_home.htm\#giniimp

Breiman, L., Friedman, J. H., Olshen, R. A., and Stone, C. I. 1984. Classification and Regression Trees. CRC Press, New York.

Chiang, H. C. 1973. Bionomics of the northern and western corn rootworm. Annu. Rev. Entomol. 18:47-72.

Claflin, L. E. 1999. Goss's bacterial wilt and blight. Pages 4-5 in: Compendium of Corn Diseases, 3rd ed. D. G. White, ed. American Phytopathological Society, St. Paul, MN.

Copes, W. E., and Scherm, H. 2010. Rhizoctonia web blight development on container-grown azalea in relation to time and environmental factors. Plant Dis. 94:891-897.

Davis, V. M., Gibson, K. D., Mock, V. A., and Johnson, W. G. 2009. In-field and soil-related factors that affect the presence and prediction of glyphosateresistant horseweed (Conyza canadensis) populations collected from Indiana soybean fields. Weed Sci. 57:281-289.

Dowdy, S., Wearden, S., and Chilko, D. 2004. Contingency table analysis. Pages 108-110 in: Statistics for Research, 3rd ed. John Wiley \& Sons Inc., Hoboken, NJ.

Eggenberger, S., Diaz-Arias, M. M., Gougherty, A. V., Nutter, F. W., Jr., Sernett, J., and Robertson, A. E. 2016. Dissemination of Goss's wilt of maize and Clavibacter michiganensis subsp. nebraskensis from inoculum point sources. Plant Dis. 100:686-695.

Friskop, A., Kinzer, K., McConnell, M., Liu, Z., Korus, K., Timmerman, A., and Jackson, T. 2014. First report of Goss's bacterial leaf blight and wilt of corn caused by Clavibacter michiganensis subsp. nebraskensis in North Dakota. Plant Dis. 98:1739.

Gleason, M. L., Taylor, S. E., Loughin, T. M., and Koehler, K. J. 1994. Development and validation of an empirical model to estimate the duration of dew periods. Plant Dis. 78:1011-1016.

Gross, D. C., and Vidaver, A. K. 1979. A selective medium for isolation of Corynebacterium nebraskense from soil and plant parts. Phytopathology 69: 82-87.

Hastie, T., Tibshirani, R., and Friedman, J. 2001. The Elements of Statistical Learning. Data Mining, Inference and Prediction Springer, New York.

Ikley, J. T., Wise, K. A., and Johnson, W. G. 2015. Annual ryegrass (Lolium multiflorum), Johnsongrass (Sorghum halepense), and large crabgrass (Digitaria sanguinalis) are alternative hosts for Clavibacter michiganensis subsp. nebraskensis, causal agent of Goss's wilt of corn. Weed Sci. 63:901909.

Jackson, T. A., Harveson, R. M., and Vidaver, A. K. 2007. Reemergence of Goss's wilt and blight of corn to the central High Plains. Online publication. Plant Health Prog. doi:10.1094/PHP-2007-0919-01-BR

Johal, G. S., and Huber, D. M. 2009. Glyphosate effects on diseases of plants. Eur. J. Agron. 31:144-152.

Kim, K. S., Taylor, S. E., Gleason, M. L., and Koebler, K. J. 2002. Model to enhance site-specific estimation of leaf wetness duration. Plant Dis. 86: 179-185.

Korus, K. A., Timmerman, A. D., French-Monar, R. D., and Jackson, T. A. 2011. First report of Goss's bacterial wilt and leaf blight (Clavibacter michiganense subsp. nebraskensis) of corn in Texas. Plant Dis. 95:73.

Korus, K. A., Ziems, A. D., Vidaver, A. K., and Jackson, T. A. 2010. Determining specificity of commercially available ELISAs for Clavibacter michiganensis subspecies. (Abstr.) Phytopathology 100:S187.

Langemeier, C. B., Jackson-Ziems, T. A., and Kruger, G. R. 2014. Four common Setaria species are alternative hosts for Clavibacter michiganensis subsp. nebraskensis, causal agent of Goss's bacterial wilt and blight of corn. Online publication. Plant Health Prog. doi:10.1094/PHP-RS-12-0160

Langemeier, C. B., Robertson, A. E., Wang, D. Jackson-Ziems, T. A., and Kruger, G. R. 2012. Factors affecting the development and severity of Clavibacter michiganensis subsp. nebraskensis of Zea mays. (Abstr.) Phytopathology 102:S5.6.

Lewis, R. J. 2000. An introduction to classification and regression tree (CART) analysis. Presented at the 2000 Annual Meeting of the Society for Academic Emergency Medicine in San Francisco, CA. Online publication. http://citeseerx.ist.psu.edu/ viewdoc/download?doi=10.1.1.95.4103\&rep=rep1\&type=pdf

Liebman, M., and Dyck, E. 1993. Crop rotation and intercropping strategies for weed management. Ecol. Appl. 3:92-122.

Mallowa, S. O., Mbofung, G. Y., Eggenberger, S. K., Den Adel, R. L., Scheiding, S. R., and Robertson, A. E. 2016. Severe wounding is not necessary for infection of maize by Clavibacter michiganensis subsp. nebraskensis. Plant Dis. 100:724-731.

Malvick, D., Syverson, R., Mallov, D., and Ishimaru, C. A. 2010. Goss's bacterial wilt and blight of corn caused by Clavibacter michiganense subsp. nebraskensis occurs in Minnesota. Plant Dis. 94:1064.

Peters, R. D., Sturz, A. V., Carter, M. R., and Sanderson, J. B. 2003. Developing disease-suppressive soils through crop rotation and tillage management practices. Soil Tillage Res. 72:181-192.

Quinn, G. P., and Keough, G. P. 2002. Experimental Design and Data Analysis for Biologists, 1st ed. Cambridge University Press, New York.

Paul, P. A., and Munkvold, G. P. 2004. A model-based approach to preplanting risk assessment for gray leaf spot of maize. Phytopathology 94:1350-1357. 
Ruhl, G., Wise, K., Creswell, T., Leonberger, A., and Speers, C. 2009. First report of Goss's wilt and leaf blight on corn caused by Clavibacter michiganensis subsp. nebraskensis in Indiana. Plant Dis. 93:841.

Schlund, S., Jackson-Ziems, T. A., Kruger, G. R., Robertson, A., and Blankenship, E. 2016. Impacts of spray adjuvants on severity of Goss's wilt and leaf blight of corn in greenhouse tests. (Abstr.) Phytopathology 106:S1.8.

Schlund, S. A. 2015. Goss's bacterial wilt development and Clavibacter michiganensis subsp. nebraskensis interactions with spray adjuvants. M.S. thesis, University of Nebraska, Lincoln.

Schuster, M. L. 1975. Leaf freckles and wilt of corn incited by Corynebacterium nebraskense Schuster, Hoff, Mandel, Lazar 1972. Agricultural Experiment Station, IANR University Nebraska-Lincoln Research Bulletin 270.

Singh, R., Hollier, C., and Burks, T. 2015. First report of Goss's wilt of corn caused by Clavibacter michiganensis subsp. nebraskensis in Louisiana. Plant Dis. 99:1268.

Smidt, M., and Vidaver, A. K. 1986. Population dynamics of Clavibacter michiganense subsp. nebraskense in field-grown dent corn and popcorn. Plant Dis. 70:1031-1036.

Strunk, C. 2012. Goss's wilt attacking South Dakota maize fields early. Online publication. IGrow, South Dakota State University Extension. http://igrow. org/agronomy/corn/gosss-wilt-attacking-south-dakota-corn-fields-early/

Suparyono, and Pataky, J. K. 1989. Influence of host resistance and growth stage at the time of inoculation on Stewart's wilt and Goss's wilt development and sweet corn yield. Plant Dis. 73:339-345.

Sweets, L., and Hosack, P. K. 2014. Goss's bacterial wilt and leaf blight of corn. Online publication. Integrated Pest and Crop Management, Division of Plant
Sciences, University of Missouri. http://ipm.missouri.edu/IPCM/2014/8/Goss_sBacterial-Wilt-and-Leaf-Blight-of-Corn

Therneau, T. M., and Atkinson, E. J. 1997. An introduction to recursive partitioning using the RPART routines. Tech. Rep. Ser. No. 61. Department of Health Sciences Research, Mayo Clinic, Rochester, MN.

Vidaver, A. K., and Mandel, M. 1974. Corynebacterium nebraskense, a new, orange pigmented phytopathogenic species. Int. J. Syst. Bacteriol. 24:482-485.

Williams, M. M., II, Bradley, C. A., Duke, S. O., Maul, J. E., and Reddy, K. N. 2015. Goss's wilt incidence in sweet corn is independent of transgenic traits and glyphosate. HortScience 50:1791-1794.

Williams, M. M., II, Davis, A. S., Rabaey, T. L., and Boerboom, C. M. 2009. Linkages among agronomic, environmental and weed management characteristics in North American sweet corn. Field Crops Res. 113:161-169.

Wise, K., and Mueller, D. 2011. Are Fungicides No Longer Just For Fungi? An Analysis of Foliar Fungicide Use in Corn. Online publication. APSnet Features. doi:10.1094/APSnetFeature-2011-0531

Wright, R. J. 1984. Evaluation of crop rotation for control of Colorado potato beetles (Coleoptera; Chrysomelidae) in commercial potato fields on Long Island. J. Entomol. 77:1254-1259.

Wysong, D. S., Doupnik, B., Jr., and Lane, L. 1981. Goss's wilt and corn lethal necrosis: Can they become a major problem? Pages 104-130 in: Proc. Annu. Corn Sorghum Res. Conf. 36th. ASTA, Washington, DC.

Wysong, D. S., Vidaver, A. K., Stevens, H., and Stenberg, D. 1973. Occurrence and spread of an undescribed species of Corynebacterium pathogenic of corn in the western corn belt. Plant Dis. Rep. 57:291-294. 